$10-2008$

\title{
Congress Should Engage in Sentencing Review: Some Ideas for the 111th Congress
}

Lisa A. Rich

Texas A\&M University School of Law, larich@law.tamu.edu

Follow this and additional works at: https://scholarship.law.tamu.edu/facscholar

Part of the Law Commons

\section{Recommended Citation}

Lisa A. Rich, Congress Should Engage in Sentencing Review: Some Ideas for the 111th Congress, 21 Fed. Sent. R. 17 (2008).

Available at: https://scholarship.law.tamu.edu/facscholar/75

This Article is brought to you for free and open access by Texas A\&M Law Scholarship. It has been accepted for inclusion in Faculty Scholarship by an authorized administrator of Texas A\&M Law Scholarship. For more information, please contact aretteen@law.tamu.edu. 


\section{Congress Should Engage in Sentencing Review: Some Ideas for the 111th Congress}

The June 2008 edition of the Federal Sentencing Reporter highlighted a fact that we have all witnessed this election season: crime and criminal justice policy are not at the top of the list of political concerns. And the presidential and congressional candidates certainly are not campaigning on a platform of sentencing reform. Given the country's current economic concerns, it is unlikely that criminal justice policy, let alone sentencing policy, will be the first concern for either a new Congress or a new administration. But these issues definitely should not be the last. Sentencing and criminal justice policy should take a prominent place in the agenda for the 111th Congress. The Supreme Court has left the sentencing "ball" in Congress's court.' It is time for Congress to engage in the process.

Since the Booker decision, Congress has demonstrated, for the most part, remarkable restraint against "tinkering" with the system, a fact owed in large measure to the efforts of the United States Sentencing Commission to keep Congress informed about federal sentencing trends. ${ }^{2}$ The Commission has done an admirable job in turning around its data collection, analysis, and reporting functions to provide Congress, and the entire criminal justice system, with useful statistics and information that suggest the system is not falling apart. For example, the Commission's efforts demonstrate, as Frank Bowman noted, that the average sentence in federal cases did rise between the pre-Booker 2005 time period (median sentences of 43.8 months) and fiscal year 2007 (51.8 months). Looking at this statistic suggests that the system is not spinning out of control across the board resulting in every federal offender receiving a probationary sentence. Moreover, despite the Department of Justice's concerns immediately after Booker that it would lose leverage to gain cooperation from defendants, not only has the rate of substantial assistance motions remained relatively steady, the percentage of government-sponsored below-range sentences has continued to increase since Booker. ${ }^{3}$

However, the trend in sentencing increases may be at an end. The average sentence length reported by the Commission did not change between fiscal year 2006 and fiscal year 2007, and recently released data for the third quarter of fiscal year 2008 demonstrate an average sentence length of 50.9 months. ${ }^{4}$ But focusing on average sentence lengths does not help move the criminal justice system from being one that is "good enough" to one that reflects not only the goals and purposes of sentencing, but the core values of this country, a fact clearly recognized by the contributors to the June 2008 edition of the Federal Sentencing Reporter. A far more sophisticated analysis and review is required.

The Supreme Court has significantly altered the sentencing landscape, perhaps more so with its Rita, ${ }^{5} \mathrm{Gall}_{\text {, }}{ }^{6}$ and Kimbrough 7 decisions than it did even with Booker. These post-Booker decisions helped define the remedial holding in Booker but more than that, they further enhanced the role of the judiciary perhaps at the expense of congressional sentencing authority. It is time for Congress to engage in the sentencing review process as part of its overall review of criminal justice policy and determine what role it desires to play in the sentencing process. As part of its review, Congress must determine whether it can be content to set only statutory maxima (and, for now, minima) thus leaving intervening sentences to judicial discretion $^{8}$ or whether it wants to continue to exercise more authority over the spectrum of sentencing within the bounds of the Constitution. 9

Becoming engaged in the sentencing review process does not mean massive overhaul in a short period of time. There are several actions that Congress could take that would result in immediate improvements to the federal sentencing system, and provide Congress with the tools it needs to begin its evaluation of sentencing policy. What follows are my top five recommendations for the 111th Con. gress. The first three I believe will result in relatively little political consternation for Congress. The last two suggestions are more political but nonetheless should be undertaken quickly for the good of the system.

\section{Request More Prison Impact Assessments}

Congress has a very important yet under-utilized tool at its disposal for assessing the affects of criminal legislation on the community: prison impact assessments. Congress must start requesting more prison impact assessments as part of its promulgation of criminal sentencing policy.

Section 4047 of title 18 , United States Code, directs the Commission and the Department of Justice to provide "information relating to a pending measure or matter that

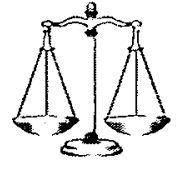

LISA A. RICH*

Visiting Professor of Law, University of Wyoming's College of Law

Federal Sentencing Reporter, Vol. 21, No. 1, pp. 17-22, ISSN 1053-9867 electronic ISSN 1533-8363 (C) 2008 Vera Institute of Justice. All rights reserved. Please direct requests for permission to photocopy or reproduce article content through the University of California Press's Rights and Permissions website, $\mathrm{http} / /$ www.ucpressjournals.com/reprintInfo.asp. DOI: 10.1525/fsr.2008.21.1.17. 
might affect the number of defendants processed through the Federal criminal justice system." ${ }^{10} \mathrm{~A}$ prison impact assessment shall include

I. projections of the impact on prison, probation, and post-prison supervision populations;

2. an estimate of the fiscal impact of such population changes on Federal expenditures, including those for construction and operation of correctional facilities for the current fiscal year and five succeeding fiscal years;

3. an analysis of any other significant factor affecting the cost of the measure and its impact on the operations of components of the criminal justice system; and

4. a statement of the methodologies and assumptions utilized in preparing the assessment."

The Commission provides prison impacts to Congress in a variety of ways. For example, congressional staff may ask for prison impact as a bill is progressing through committee. For, example, the House Judiciary Committee fairly regularly asks for prison impact assessments or other similar types of information when a bill is being considered in committee. ${ }^{12}$ It also routinely requests such assessments when a bill is reported out of committee. When that occurs, the Commission works with the Congressional Budget Office to produce a prison impact assessment, which is incorporated into the bill's budget estimate. The Commission generally supplies the number of beds affected and other matters of interest and the Congressional Budget Office provides the cost of those beds. ${ }^{13}$ Interestingly, prison impact assessment requests were far more common during the rogth Congress when every bill reported out of the House Judiciary Committee contained a mandatory minimum provision. ${ }^{14}$

Even more important than prison impact assessments for individual bills, Congress should require the Department of Justice to comply with the reporting requirements set forth in section 4047 (c). That section requires that by March I of every year, the Department of Justice provide to Congress "a prison impact assessment reflecting the cumulative effect of all relevant changes in the law taking effect during the preceding calendar year." ${ }^{15}$ Requiring the Department of Justice to comply with this reporting requirement would provide significant insight into the formulation of criminal justice policy because the reporting requirement covers all criminal justice legislation, not just that implementing statutory mandatory minima. Congress should include review of this report in its regular Department oversight hearings. Doing so would allow Congress and the Department to assess the previous year's criminal justice policy in a meaningful and effective manner.

\section{Reaffirm the Appropriateness of Statutory Directives to the Commission}

Seventy-four bills were introduced during the rroth Congress containing directives to the Commission. ${ }^{16}$
Ultimately, eight bills were enacted with directives to the Commission on substantive criminal law including disaster fraud, ${ }^{17}$ theft from veterans' memorials, ${ }^{18}$ drug trafficking, ${ }^{19}$ and regulation of online pharmacies and controlled substances. ${ }^{20}$ Complying with these directives will require a considerable amount of work by the Commission to independently evaluate each of these areas and ascertain what, if any, Guideline amendments are appropriate.

Many have suggested over the years that when the Commission receives a directive from Congress that directive usurps the Commission's independence and the resulting Guidelines are, therefore, infirm. ${ }^{21}$ This line of criticism has taken on new meaning since the Court concluded in Kimbrough that sentencing courts could disagree with a Guideline on policy grounds, including that the Commission did not exercise its traditional, independent role when formulating the Guideline. ${ }^{22}$ This language is now being used repeatedly by defense counsel to attack the reasonableness of a Guideline sentence in instances where the guideline was promulgated as a result of a congressional directive. ${ }^{23}$

Congress must address this erosion of its ability to express its sentencing intent through the Commission. The Commission always prefers that Congress not include directives in legislation; however, directives often are the result of a legislative compromise to pass a bill that otherwise would not have been passed or, worse, would have been passed with statutory minimum mandatory sentences.

Congress, in the short term, should address the issue of directives in legislation and particularly the post-Gall/Kimbrough critique being leveled against them by (I) specifically recognizing congressional authority over sentencing and the propriety of exercising that authority through statutory directives; and (2) issuing only broad directives to the Commission to "study and amend" the Guidelines, which combines analysis and appropriate amendments in a way that "closely adheres to the manner in which the Sentencing Reform Act indicated the Sentencing Commission should the evolutionary task of improving its guidelines and policy statements." ${ }^{24}$

Congress gave the Commission a very clear set of instructions to follow when promulgating Guidelines or amendments thereto. Those instructions are set out in both titles 18 and 28 and include a totality of circumstances to be considered. Congress should not impede that analysis by issuing specific directives such as specific enhancement levels for a particular offense ${ }^{25}$ or directing the Commission to interpret changes made by an Act in a certain way. ${ }^{26}$ Congress can and should direct sentencing policy from the minimum through the maximum but it should do so carefully and in a way that relies on the tool that it created to undertake this process: the independent Commission. 


\section{Instruct the Commission to Take the Lead in Sentencing Review and Require Detailed and Specific Information}

Congress should demonstrate the same thoughtful, bi-partisan approach to sentencing review that it did during the reform movement that led to passage of the Sentencing Reform Act. The principles that guided that reform movement should be reaffirmed by Congress and used as the framework for its latest review of sentencing policy. The initial review of sentencing policy should be removed, to the furthest extent possible, from political machinations and be based on sound evidentiary findings. How can Congress, a political body like no other, accomplish such a task? For starters, Congress should embrace the Commission's apparent desire to take a leading role in the sentencing review process.

In its recently published priorities for the year, the Commission indicates that it hopes to continue its work with all three branches of government on issues of interest since Booker. Specifically, the Commission may consider

(A) an evaluation of the impact of those decisions on the federal sentencing guideline system, (B) development of amendments to the federal sentencing guidelines, (C) development of recommendations for legislation regarding federal sentencing policy, and (D) a study of statutory mandatory minimum penalties. ${ }^{27}$

Congress should require the Commission provide detailed and meaningful analyses of the state of federal sentencing in this country, including requesting specific information that provides-

I. Detailed and comprehensive analysis of individual offense types, including by drug type; ${ }^{28}$

2. Detailed regional and interregional studies of sentencing trends; ${ }^{29}$

3. Detailed assessments of any racial disparities arising in the system; ${ }^{30}$

4. Detailed analysis of the increase in noncitizens in the federal system; ${ }^{3 r}$

5. Detailed examination of mandatory minimum sentences and their interaction with an advisory Guideline system; ${ }^{22}$

6. Detailed analysis of the use of acquitted, dismissed, or uncharged conduct at sentencing; 33 and

7. Specific statutory and Guideline amendments that would allow the sentencing system to operate more effectively, including the efficacy of expanding the safety valve, ${ }^{34}$ retaining or repealing the " 25 percent rule," 35 de-linking the Guidelines from mandatory minimums, ${ }^{36}$ statutory relief from some or all congressional directives, inclusion of more alternatives to incarceration, ${ }^{37}$ and other suggestions that the Commission deems appropriate.

Congress expected the Commission to be the expert on federal sentencing issues and provide it with advice and guidance on the evolution of sentencing. ${ }^{88}$ The Commission should revel in that role and engage all of its resources to this end. The Commission is uniquely situated to interact with all the relevant stakeholders in sentencing policy, including holding national and regional hearings, conducting detailed analysis of sentencing information, and processing information in a bipartisan, independent way. Congress should let the Commission operate and report back within a year or so with the information Congress can use to further structure sentencing in this country.

The last two recommendations are political in nature and will require Congress to act in consultation with a new administration. Taking such action may not be palatable to a new Congress and a new administration but they are essential to the effective operation of federal sentencing policy.

\section{Ensure a Full Slate of Commissioners}

In the waning days of the IIoth Congress, members quietly undid one of the more opaque provisions of the 2003 PROTECT Act, which required that no more than three of the Commission's members could be federal judges. ${ }^{39}$ Nothing in the legislative history of the PROTECT Act provides background for this change, which did not appear in the Act until very early in the morning of the day it was debated on the Senate floor. The provision garnered a great deal of criticism and remained one of the most uncomfortable results of the PROTECT Act that the Court's Sixth Amendment jurisprudence could not affect. As part of the Judicial Administration and Technical Amendments Act of $2008,4^{\circ}$ Congress returned the language to its pre-PROTECT Act days so that membership of the Commission must contain at least three federal judges, thus reinstating the language that Congress included in the Sentencing Reform Act.

As discussed above, the Commission provides Congress with an independent, expert body designed to be the clearinghouse on federal sentencing issues. ${ }^{\mathrm{I}}$ The Commission has demonstrated its ability to inform the criminal justice system time and time again since the Booker decision about matters of federal sentencing practice and its independent, expert voice on the subject has quelled fears of an advisory system run amok. Congress should expect the Commission to take a leadership role in the sentencing review process. To that end, Congress and a new administration must ensure that the Commission remains at full strength.

\section{Conclusively Address the Issue of Federal Cocaine Sentencing}

Congress must move past the politics associated with this topic and conclusively address the unwarranted disparity that currently exists between federal crack cocaine and powder cocaine sentences. While the Commission's actions in this area are laudable, they did not adequately address the problems associated with this piece of criminal justice 
policy. In fact, because the Commission could only adjust the Guidelines slightly because of the required linkage to the mandatory minimums established by Congress, it could be argued that the Commission's action introduced even more disparity into the system because of the wide range of drug ratios that now exist between crack cocaine and powder cocaine. The sentencing provisions governing federal cocaine offenses result in such a negative perception of criminal justice in this country that they simply cannot be justified. $4^{2}$

If Congress undertakes even some of the actions outlined above, the federal sentencing system in this country will operate more effectively and a thorough examination of sentencing without respect to politics is possible.

\section{Notes}

- Lisa Rich is currently a visiting professor of law at the Univer. sity of Wyoming's College of Law where she is teaching constitutional law, legal writing, legislation, and federal sentencing. Before entering full-time academia, Ms. Rich was the Director of Legislative and Public Affairs for the United States Sentencing Commission.

1543 U.S. 220 (2005).

2 The change in congressional leadership during the 110th Congress of course also contributed to the lack of response to Booker and its progeny but even the 109th Congress was relatively contained in its response to Booker relying as it did on mandatory minima for specific offenses rather than a wholesale sentencing "fix."

3 Compare U.S. Sentencing Commission 2005 Sourcebook of Sentencing Statistics, Fig. G (post-Booker 2005) with U.S Sentencing Commission 2006 Sourcebook of Sentencing Statistics, tbl. N; U.S. Sentencing Commission 2007 Source. book of Sentencing Statistics, tbl. N; and U.S. Sentencing Commission Preliminary Quarterly Data, tbl. 1 (available at http://www.ussc.gov/sc_cases/USSC_2008_Quarter_Report_ 3rd.pdf). A note of caution on this overall statistic is impor. tant, however. The number of immigration cases also has significantly increased during this time period so the number of "fast track" or "early disposition" departures has increased, which appear to have contributed somewhat to the increase in government sponsored below-range sentences.

4 Compare U.S. Sentencing Commission 2005 Sourcebook of Sentencing Statistics, tbl. 13 (pre-Booker); U.S. Sentencing Commission 2006 Sourcebook of Sentencing Statistics, tbl. 13; U.S. Sentencing Commission 2007 Sourcebook of Sentencing Statistics, tbl. 13 with U.S. Sentencing Commission Preliminary Quarterly Data, tbl. 19 (available at http://www.ussc.gov/sc_cases/USSC_2008_Quarter_Report_ 3rd.pdf). The drop in average sentence length in fiscal year 2008 could be attributable to the Commission's recent activity with respect to crack cocaine offenses, which comprise a significant number of cases in the federal docket. If the average sentence length for fiscal year 2008 does in fact turn out to be lower than previous years, the Commission should try to ascertain what caused the decrease, specifically whether the decrease is due to the change in crack cocaine sentences.

5 Rita v. United States, 551 U.S. _, 127 S. Ct. 2456 (2007).

6 Gall v. United States, 552 U.S. _, 128 S. Ct. 586 (2007).

7 Kimbrough v. United States, 552 U.S. _, 128 S. Ct. 558 (2007).

8 Many critics now argue that a directive to the Commission is just that, a directive to the Commission and not the courts and therefore, there should be no congressional directives because in an advisory system, the Guidelines are now just one factor to be considered under 18 U.S.C. $\S 3553($ a). Con- gress should consider this argument and if it determines that a directive to the Commission is, by the nature of the interaction between titles 28 and 18 , United States Code, a direction to the courts, it should reaffirm that belief.

9 As discussed in more detail, infra, it certainly seems as if Congress desires to exercise authority over sentencing beyond setting minima and maxima given the number of directives Congress issued to the Commission during the 110 th Congress. The 110 th Congress certainly seems to have believed that the Commission's independence and expertise in setting penalties through the Guidelines was a better alter. native than establishing statutory mandatory minima or amending the Guidelines directly.

1018 U.S.C. $\$ 4047$ (b) (West 2008).

11 Id.

12 Because of its internal processes, the Senate is less likely to issue a report accompanying legislation or request a budget assessment of pending legislation but it could still utilize section 4047 as part of its deliberative processes.

13 This arrangement between the Commission and the Congres. sional Budget Office is somewhat informal and is the result of concerns expressed early in the Commission's existence that it report financial projections associated with prison impact assessments. As a result, the Commission provides the raw number of beds and other substantive information to the Congressional Budget Office, which then gets the cost per bed from the Bureau of Prisons. The resulting cost is then made a part of the final budget estimate and report that accompanies a piece of legislation.

14 The Commission's statutory prison impact assessments are limited in the information they can model; a change in the statutory maximum, for example, is too difficult to model because there is no way of knowing where between the mini. mum and maximum a sentence might fall. Modeling the difference between no minimum and a set minimum can be accomplished easily. This should not dissuade Congress from aggressively using section 4047 as part of its criminal justice policymaking. Certainly, there should be a way to provide prison impact assessments on pending legislation as this is a tool commonly employed by state sentencing commissions.

1518 U.S.C. $\$ 4047$ (c) (West 2008). I am not aware of this report ever having been filed during my tenure at the Com mission. Perhaps it is part of other annual Department reports but Congress should require that it be sent separately given the significant contribution it could make to the formulation of criminal justice policy.

16 Some of these bills represent multiple versions of a single substantive bill.

17 Pub. L. 110.179, 121 Stat. 2556 (2008),

18 Pub. L. 110.384 (2008) (directing the Commission to ensure enhanced penalties for theft of veterans' memorials and grave markers).

19 Pub. L. 110.407 (2008) (directing the Commission to review and amend the Guidelines, if necessary, for drug trafficking crimes involving submersible vessels).

20 Pub. L. 110-425 (2008) (directing the Commission to review the Guideline penalties for certain scheduled substances).

21 The Commission's Fifteen Year Review is often cited to sup port this attack on congressional directives. See generally, U.S. Sentencing Commission Fifteen Years of Guidelines Sen. tencing: An Assessment of How Well the Federal Criminal Justice System is Achieving the Goals of Sentencing Reform 77 (2004). But the Fifteen Year Review does not necessarily reflect the current, or former, Commission's view of direc. tives. For example, the Commission's 1991 Report to Congress on mandatory minimum penalties noted that while specific directives to the Commission may be "in tension" with the Commission's fundamental independence, a "study 
and amend' directive is a highly effective means of congres sional influence over sentencing policy. Special Report to Congress: Mandatory Minimum Penalties in the Federal Criminal Justice System 121, 124 (1991). As part of its review of the sentencing system, the current Commission should review the statements in the Fifteen Year Review and the Commis. sion's other reports to determine if empirical evidence and national experience continue to support them.

22 Kimbrough, $128 \mathrm{~S}$. Ct. at 570 . In its recent submission to the Commission on its proposed priorities, the Federal Defenders suggest that Booker's full "positive impact" "will not be felt" until the Commission "amends those guidelines that are not based on empirical evidence or national experience." Letter to Ricardo $H$. Hinojosa from Jon M. Sands at 4 (Sept. 8 2008). The Defenders specifically suggest that the Commis. sion "not take any action to implement crime legislation unless it is based on its own expert evaluation of the need for changes in the guideline structure." Id. at 46.

23 The Federal Defenders Service has launched an extensive research program that seeks to "deconstruct" the Federal Sentencing Guidelines and provide defense counsel with arguments against Guidelines promulgated as a result of congressional directive, particularly those covering child pornography offenses and career offenders. See the Federal Defenders Sentencing Resource page, Deconstructing the Guidelines project at http://www.fd.org/odstb_SentencingRe. source 3.htm\#DECONS. Sentencing courts have taken these arguments to heart and several have concluded that the Guidelines were not the product of the Commission's independent and expert decision-making could be disregarded. See, e.g., United States v. Rodriguez, 527 F.3d 221 (1st Circuit 2008) (fast track); United States v. Sanchez, 517 F.3d 651 (2d Cir. 2008) (career offender); United States v. Rausch, _ F. Supp. 2d, 2008 WL 3411819 (D. Col., Aug. 13. 2008) (child pornography). Admittedly, the government opened the door to this argument in its Kimbrough brief in which it stated that as long as "Congress expresses its will wholly through the Guidelines system, the policies in the Guidelines will best be understood as advisory under Booker." Br. of the United States at 29.

241991 Mandatory Minimum Report at 124. As Paul Hofer sug. gests in the June 2008 Federal Sentencing Reporter, an "advisory system with guidelines based on research, consul. tation with front-line participants, and reasoned deliberation" is an effective system. That system can coexist with congressional directives if those directives are tailored effectively.

25 See, e.g., H.R. 5652, the Child Sexual Slavery Prevention Act of 2008, which directs the Commission to amend USSG $\S 2 \mathrm{H} 4.1$ to provide, among other things, a four-level increase in the base offense levels; a six.level I increase if the victim is under the age of eighteen. As another example, when H.R. 3480 (see n.19, supra) was originally introduced, the legislation directed the Commission to review and amend the Guidelines to provide a sentencing enhancement desecration or theft of veteran's grave markers. Working with congres. sional staff, the Commission was able to change the directive to allow the Commission to exercise its own independent analysis of the Guidelines and amend the Guidelines only "if appropriate." This type of directive best expresses congres. sional intent and allows the Commission to act based on empirical evidence and its own independent analysis.

26 The directive in H.R. 6353, the Ryan Haight Online Pharmacy Consumer Protection Act of 2008, is an example of a direc. tive that is, in my opinion, too specific and establishes bad precedent for future directives. The act directs the Commis. sion to review the Guidelines and amend them in accordance with the act but not to consider increases in statutory max. ima for certain scheduled substances as the sole reason to amend the Guidelines. The Commission does not consider increases in statutory maxima as the only reason to increase penalties under the Guidelines. The Sentencing Reform Act articulates specific factors that the Commission must con. sider whenever it promulgates an amendment to the Guidelines, and changes in statutory maxima are one of those factors. If Congress was concerned about this being the "sole" reason the Commission would act, it could have expressed concern in another way, such as through report language or floor statements. Now, it appears that either the Commission routinely considers statutory maxima increases as the only reason to increase a Guideline (which it does not) and this directive represents the new norm, or worse, if future commissions were of such a mind, they could interpret this directive as isolated and the next time a directive does not contain such language, determine that increases in statutory maxima alone are sufficient for changes to the Guideline. Either way, this directive is an unnecessary instruc tion to the Commission that sets bad precedent for future congressional and Commission action.

27 Federal Register Notice of Final Priorities, BAC2211-01, available at http://www.ussc.gov/FEDREG/20080908_ Finalpriorities.pdf.

28 As part of this analysis, the Commission should provide a detailed report of the effect of its crack cocaine amendment, including whether that is the cause of the apparent drop in national average sentence length. The Commission should also include a report on the impact of the crack cocaine amendment's retroactive application. It was apparent during the 110th Congress that some in Congress were concerned about the Commission's authority to give retroactive effect to an amendment without congressional input. See 28 U.S.C. $\S$ 994(u). The Commission should take the opportunity to demonstrate to Congress that its original decision to give this authority to the Commission was appropriate.

29 There is growing concern about regional and inter-district dis parities arising across the country. The Commission should provide Congress a detailed accounting of sentencing prac. tices so that if such disparities exist, Congress and the criminal justice community can determine if they are in fact unwarranted.

30 Senator Biden and Representative Cohen introduced compan ion bills in the 110th Congress calling for an examination of racial and ethnic disparities throughout the criminal justice process, from charging through sentencing. See S. 3245 and H.R. 6518 (both entitled "Justice Integrity Act of 2008"). Both bills direct the Attorney General to establish an advisory group comprised of policy stakeholders throughout the crim. inal justice process including U.S. attorneys, defense counsel, judges, and community activists. Hopefully, these bills will be introduced in the 111 th Congress and if they are, Congress should seriously consider involving the Commission in this process. The Commission has unique (and immediate) access to a variety of sentencing related information that could assist in this important evaluation.

31 This analysis should include issues associated with non-citi. zens ineligibility for alternatives to incarceration and rehabilitative programs that may be available for citizen offenders.

32 The Commission should provide Congress a current report similar to its 1991 mandatory minimum report. This report should expand upon the testimony Judge Hinojosa gave during the House mandatory minimum hearing in June 2007 , including a detailed examination of how the increased severity and number of mandatory minimums have impacted the system since 1991. Historically, the Commission opposed mandatory minimums because the Guidelines themselves were mandatory and could provide certainty and trans. 
parency in a way that was not "one-size-fits-all." Clearly, that is no longer the case and the Commission should provide specific reasons why it believes mandatory minimums are not necessary in an advisory system, if that is what it believes.

33 Significant criticism has been levied against the Commission and federal sentencing practices resulting from the use of acquitted, dismissed, or uncharged conduct during sentenc. ing. Courts have upheld the use of acquitted conduct at sentencing, even after Booker. And 18 U.S.C. $\$ 3661$ specifically states that a court is not limited as to what information it may consider at sentencing. It remains offensive to many; however, that conduct for which a defendant was acquitted, in particular, can be used at sentencing. During Representa. tive Bobby Scott's "Crime Summit" in June 2007, suggestions were made that acquitted conduct is used to sen tence defendants in the majority of federal cases. Given that barely 3 percent of federal cases go to trial, it is impossible that acquitted conduct is used with any real frequency. To better understand the frequency with which courts consider such conduct, the Commission should provide a detailed analysis of those cases that have gone to trial. It may be more difficult to provide information on the use of dismissed or uncharged conduct but the Commission is the best place to start for such information.

34 The Commission has repeatedly testified about the need to expand the safety valve provision (18 U.S.C. $\S 3553(f)$ ) beyond drug offenses and FAMM's recent report on manda. tory minimums also recommends expansion of the safety vaive. See Correcting Course: Lessons from the 1970 Repeal of Mandatory Minimums (2008).

3528 U.S.C. $\S 994(b)(2)$ (West 2008). The "25 percent rule" requires the top of the applicable Guideline range be no greater than 25 percent of the bottom. The rule is one of the reasons why the Sentencing Table comprises 243 cells. The Commission should examine whether such a rule is useful in a post-Booker advisory Guideline system.

36 The PROTECT Act amended section 994(a) to require that the Guidelines be consistent with all applicable federal statutes. The language was first introduced in 1995 (by Democrats) after the Commission promulgated its amendment to the Guidelines changing the ratio of crack cocaine and powder cocaine from 100-to-1 to 1-to-1. The original language of the Sentencing Reform Act required the Guidelines only to be consistent with title 18, United States Code which, of course, does not contain the drug trafficking statutes. Congress rein. troduced the language in succeeding congresses and it was finally enacted as part of the PROTECT Act.

37 The Commission's July 2008 symposium on alternatives to incarceration brought together experts from across the coun. try to share their experiences with implementing alternatives to incarceration. The Commission should provide whatever information it can to Congress on programs and approaches demonstrated during the symposium that could work on the federal level.

38 Congress also should include the Commission in whatever federal task forces or review bodies that it establishes. For example, the racial disparity bills introduced in the 110 th Congress included representatives from virtually every aspect of the criminal justice system except the Commission. Yet the Commission routinely interacts with these entities on matters of sentencing policy and may be in the best position to pro. vide useful information on sentencing practices, trends, and policies. Congress should be sure to utilize the Commission and the powers it gave it whenever possible. In turn, the Com. mission should be prepared to take a leadership role in sentencing policy development, including providing detailed and in.depth studies and analyses on relevant issues.

39 See 28 U.S.C. $\$ 991$ (2008).

$40 \quad$ S.3569, § 16 (2008). Pub. L. 110.406

4128 U.S.C. $\$ 995(a)(12)(A)$

42 I recognize and appreciate law enforcement concerns that changing the law could lead to more drug trafficking and violence; however, that has to be weighed by community perceptions of unfairness in the system. Congress must reach an appropriate balance between these competing interests and conclusively address this issue. $I$ also understand the Department's belief that cocaine sentencing reform should be part of a larger examination of sentencing in this country because of the myriad issues associated with it such as the Commission's authority to give a Guideline retroactive effect. That said, Congress has been considering this issue for more than a decade. The time has long since passed for it to act. Congress should seek from the Commission, the Depart ment, and other sources whatever information it deems necessary to address this issue expeditiously. 